\title{
Medina's Habitation as a Sustainable Investment Factors: Thermal Experience
}

\author{
Ali Hadjala1,*(i), Said Mazouz² \\ ${ }^{1}$ Faculty of Architecture and Urban Planning, Salah BOUBNIDER University Constantine 3; \\ quartz-ali@hotmail.fr \\ 2 Faculty of Earth Sciences and Architecture, Larbi BEN M'HIDI University Oum El Bouagui; \\ s mazouz dz@yahoo.fr \\ *HADJELA Ali: quartz-ali@hotmail.fr; Tel: 00213661518667.
}

Keywords: Medina; Thermal; Materials; Energy; Functional Space; Form; Heritage; Model; Sustainable Development.

\begin{abstract}
The study examined significant summer heat effects on a traditional habitation cluster within a compact fabric of the Medina of Constantine, based on building materials and spatial functional architecture. As climate relates to energy effects, the study raises the importance of possible heat gains in the approach of thermal comfort through building materials without using other energy sources. The study employed both empirical and comparative methods to undertake the research work. The empirical method consisted of taking thermal and metric measurements of the habitation cluster and comparing them with current normative requirements in sustainable architecture. The comparative method consisted of comparing results of performance assessment of studied building materials with results of similar materials. The current study adds to researchers' claims about the importance of the Medina's habitation in the face of climatic aggression at times with its architecture and building materials. Medina's habitat did not have the technological means to preserve some physical comfort and reduce greenhouse gas emissions, yet its architecture used soft means to accomplish the physical comfort. Additionally, the site's well-chosen materials, which are formed by the natural typology, match well with the site's climate and provide better resistance to material overflow, not to mention their availability and inexpensive cost.
\end{abstract}

\section{Introduction}

Designers of architectural styles always think of creating model buildings with the aim of generalizing or producing the "global ideal." However, the changing significance of the word "ideal" through the medieval, classical, renaissance, neoclassical, and modern times presents a strong argument for disruption in the direction of the pursued model of urban architecture, as the choice of creators has remained unstable until the end of the 19 th century with the introduction of the spirit of sustainable development. The Rio international conference for sustainable development has emphasized safeguarding the social, economic, and environmental heritage (as heralded by Sustainable Development) seems to be finally a flawless irreversible "argument" for everyone, 1992). However, the sustainable development spirit exploits ancient times practices to create a sustainable architecture (Azzag, 2011).

The Medina of Constantine, Algeria, "a traditional city, situated in the north-east of Algeria," is not spared from the world and shows its existence and pertinence (Fantazi et al., 2019). The patrimonial heritage of the Medina of Constantine, productive of buildings and housing projects, develops complex directions and above all endures the perplexities 
of time (Fantazi et al, 2019; Kherouatou, 2011; Grangaud, 1998). Notwithstanding twelve centuries of existence, the Medina of Constantine remained almost unchanged, as historical events and exogenous cultural values failed to transform or significantly modify the form of the Medina (Grangaud, 1998). This fact is interesting enough to consider the relevance of the Medina of Constantine as an enduring place in the face of climatic effects, given its geographical location (a semi-arid region) and used building materials.

Some avant-garde architects question the choice of materials traditionally used in building and seek modern conceptual techniques. Without getting bogged down in the pompous eco-rhetoric of the 1960s, some natural materials are of topicality as they are less energy voracious, have energetically interesting physical properties, and significant thermal inertia capabilities (Lacaze, 2014). André Raverau and Bernard Pagan showed the role of building materials in the distinctive socio-functional architecture of Medina's habitations. This topical subject is the issue of sustainable development. This socio-functional architecture offers physical organization, adherence to the climate, and global and detailed trans-generational perceptions without causing dysfunction. The use of this socio-functional architecture is available to all (merchants, inhabitants, craftsmen, rich, poor, etc.) and multifunctional, as it offers a space of socialization and negotiation, meeting the requirements of both ordinary and exceptional daily life (Dekoumi, 2007; Bouchareb, 2006).

\section{Materials and Methods}

The study used empirical and comparative study methods. Initially, thermal and metric measurements of the habitation cluster buildings were collected and compared with current normative requirements in sustainable architecture (Al-Mudhaffer et al, 2021). Subsequently, evaluation results of the performance of studied materials were compared with results of other similar materials. The analysis considers energetic and economic aspects. These two types of analyses can be conducted separately (in relation to the initially defined objective); yet, analysis applications should be carried out simultaneously, as the comparative method is likely to introduce corrections to the empirical evaluation. Demazièr et al. (2013) mentioned that "Comparative practices have evolved considerably over the last 20 to 30 years. The fields researched objects, issues, methods and theorizations have expanded". The study necessitated a broadened literature research on the cultural aspects of the Medina of Constantine.

Potential technical knowledge and empirical criteria derived from practice provide us cumulative information to formulate probable answers (Adegun \& Adedeji, 2017). Normative criteria, technical expertise, and legislation lend us further significant study support.

\section{Study Results}

\subsection{The case study}

A metropolis in the east of Algeria and located $400 \mathrm{~km}$ east of the capital Algiers at an altitude of $644 \mathrm{~m}$ above sea level, Constantine is one of the oldest cities in the world (2500 years). The Medina is based on a triangular mass of limestone whose base rises to the north while the summit descends to the south. The old town of Constantine has been defined as a "protected area according to Executive Decree No. 05-208 of 04 June 2005". The protected area covers a total surface of 8539 hectares according to the National Agency for Safeguarded Sectors (NASS, 2013). 


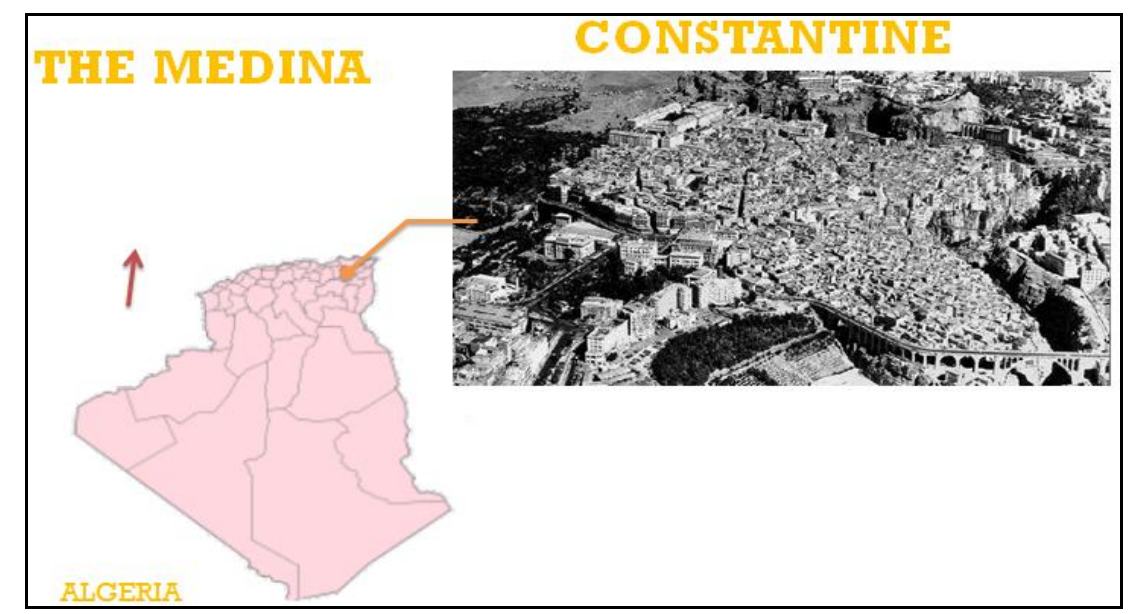

Figure 1. The situation of Constantine (source: authors)

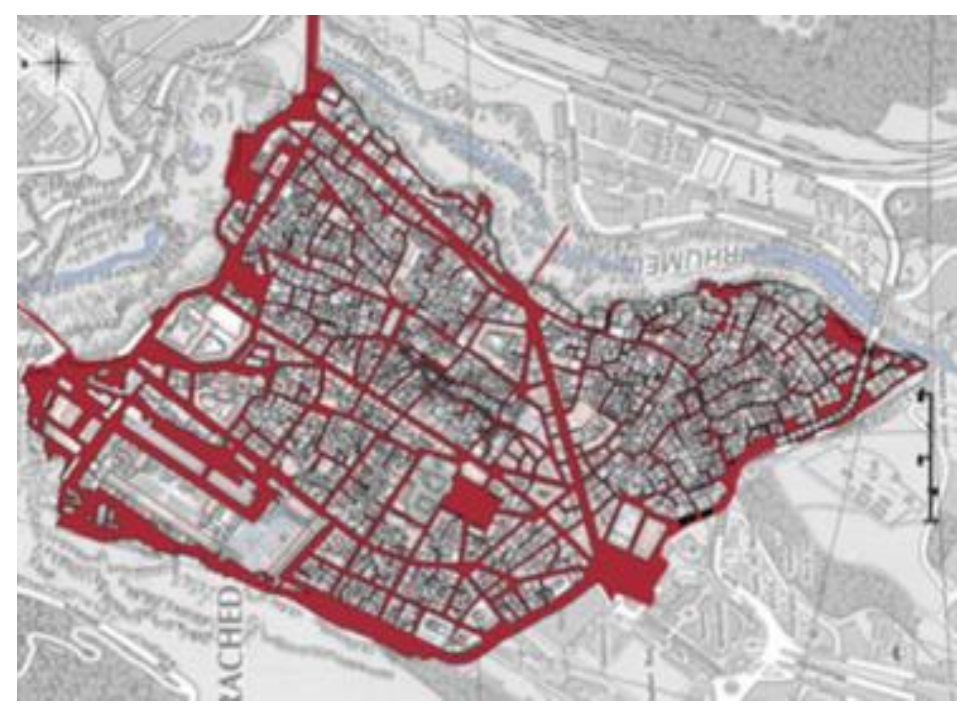

Figure 2. The Protected Area, Constantine. (Source: NASS, 2013; modified by authors)

The city of Constantine has a Mediterranean climate characterized by low temperatures in winter (reaching $-6^{\circ} \mathrm{C}$ in winter), high temperature in summer, reaching $47^{\circ} \mathrm{C}$ (Table 1), and mean precipitation ranging from $500 \mathrm{~mm}$ to $700 \mathrm{~mm}$ per year.

Table.1. Critical temperature periods in Constantine. (Source: The official website for weather in Algeria).

\begin{tabular}{lccccccccccccc}
\hline Month & Jan & Feb & Mar & Apr & May & Jun & Jul & Aug & Sep & Oct & Nov & Dec & Year \\
\hline $\begin{array}{l}\text { Mean low } \\
\text { temperature }\left({ }^{\circ} \mathbf{C}\right)\end{array}$ & 2 & 3 & 4 & 6 & 10 & 15 & 17 & 18 & 15 & 11 & 6 & 3 & 9 \\
$\begin{array}{l}\text { Mean temperature } \\
\left({ }^{\circ} \mathbf{C}\right)\end{array}$ & 7 & 8 & 10 & 12 & 16 & 21 & 25 & 25 & 21 & 16 & 11 & 8 & 15 \\
Mean high & & & & & & & & & & & & & \\
temperature $\left({ }^{\circ} \mathbf{C}\right)$ & 11 & 12 & 14 & 17 & 22 & 28 & 32 & 32 & 27 & 22 & 16 & 12 & 21 \\
Record cold $\left(\mathbf{(}^{\circ} \mathbf{C}\right)$ & -3 & -3 & -2 & -2 & -2 & 1 & 5 & 8 & 10 & 7 & 2 & -3 & -3 \\
Record heat $\left({ }^{\circ} \mathbf{C}\right)$ & 22 & 27 & 27 & 30 & 35 & 41 & 41 & 41 & 38 & 36 & 27 & 27 & 41 \\
Precipitation $(\mathbf{m m})$ & 80 & 60 & 60 & 50 & 40 & 20 & 0 & 10 & 20 & 40 & 50 & 80 & 560 \\
\hline
\end{tabular}


For the sake of the study, the period of time between June and August has been chosen for its aggressiveness (Figure 3,4).

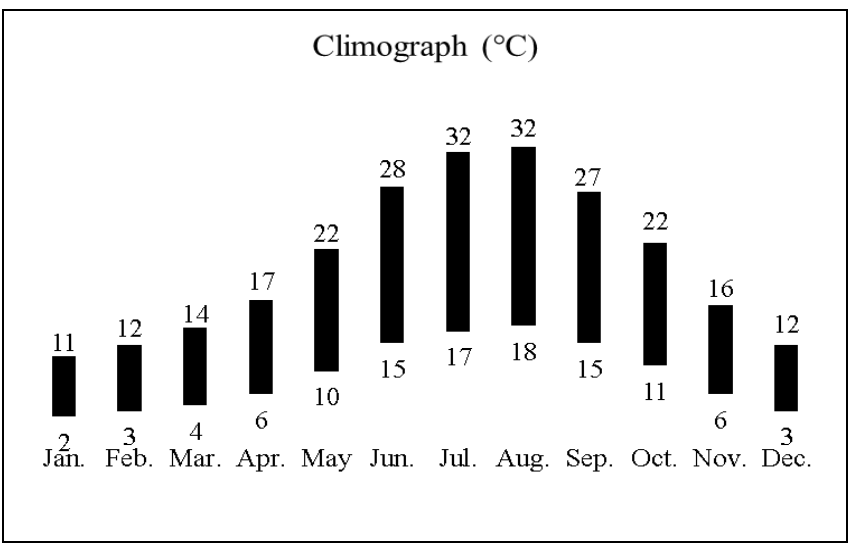

Figure 3. Mean temperature (Source: The official website for weather in Algeria).

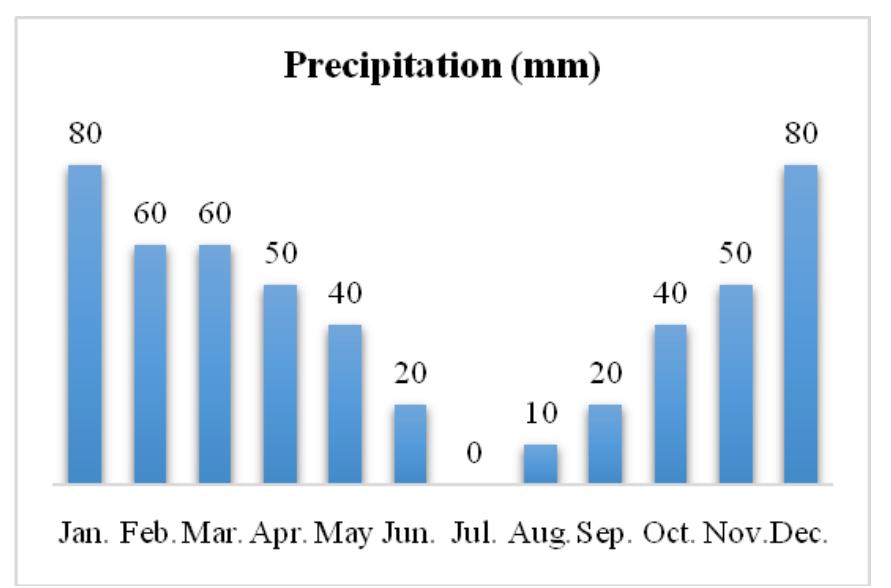

Figure 4. Mean precipitation (Source: The official website for weather in Algeria).

These climatic parameters of the habitation cluster, Derb Ben Cheikh that is an integral part of the Medina of Constantine, apply to our case study Ben Cheikh.

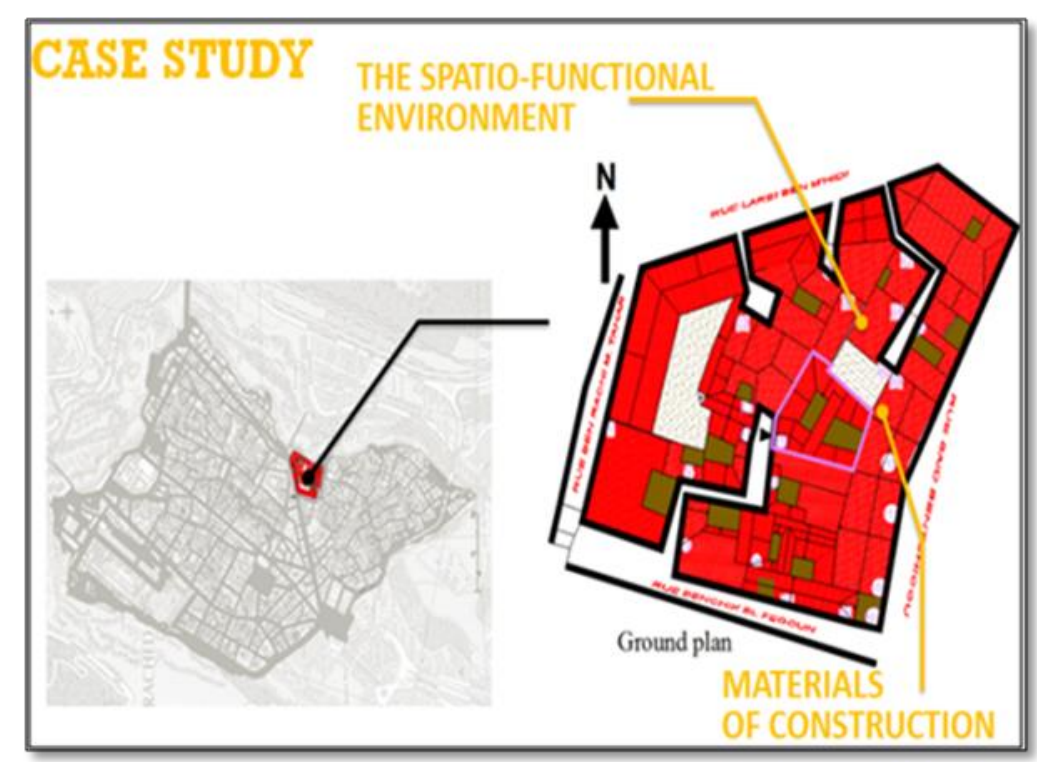

Figure 5. Case study: Habitation cluster Derb Ben Cheikh. (Source: NASS, 2013; modified by authors) 


\subsection{Thermal economy by architecture facing summer heat (empirical method)}

\subsubsection{Thermal economy by the patio}

The vernacular house in Constantine constantly maintains the balance of its indoor temperature, in summer or winter, without the use of artificial energy thanks to the patio that makes a majestic space (almost $95 \%$ of the houses have a patio) (NASS, 2013). Additionally, there is the KBOU that is a basement or half-basement storage space for food in the summertime, as neither the refrigerator nor the air conditioner was a common commodity in the Medina (these devices generate greenhouse gases harmful to the ozone layer).

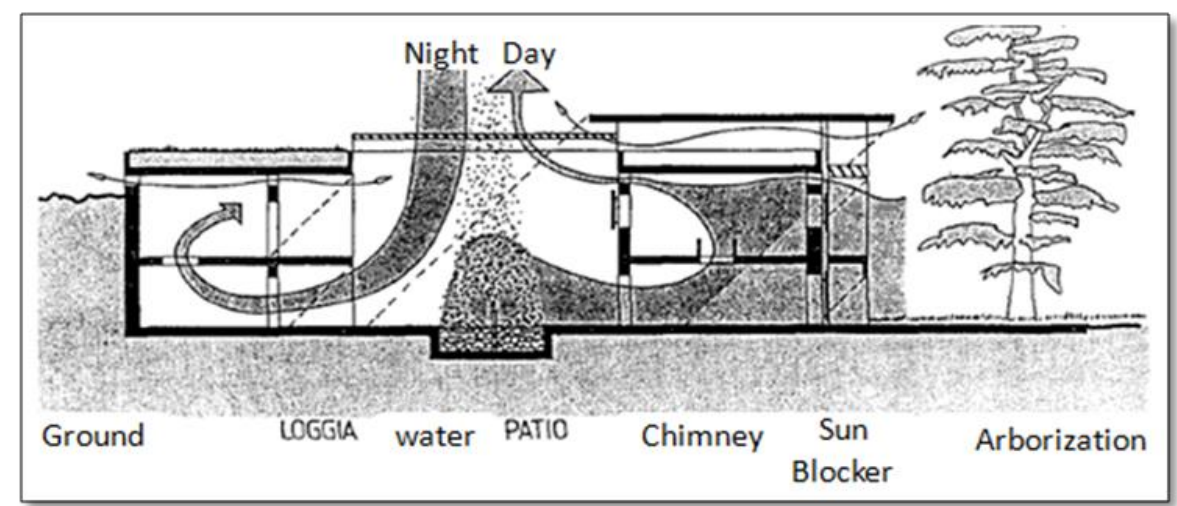

Figure 6. Patio climatic function diagram. (Source: Plemenka, 1982)

"The patio is the ultimate protection of open private space against extreme temperatures, heavy winds, and sandstorms. Meeting the oriental need for introversion, the patio is a shaded space for much of the day and behaves like a thermal regulator, as the night-time freshness fades only in the early afternoon" (Bouchareb, 2006).

In his work 'The City and the Arab-Muslim Habitation,' Said Mouline stated that "it is through the inner patio that the surrounding areas get ventilated and receive sunshine" (Mouline, 1981).

"The house is equipped with a traditional air conditioning system. It is opened to the sky by a central opening framed by porticos of galleries with 3 or 4 blind arcades following the size of the plot on four sides" (NASS, 2013)

The juxtaposition of family units reduces the horizontal transmission of temperature by conduction through the reduction of walls' surface with contact to the outside. Being dangerous to the health of inhabitants, the phenomenon of moisture is almost negligible, if not reduced to none, inhabitations with a patio (Fethi, 1977).

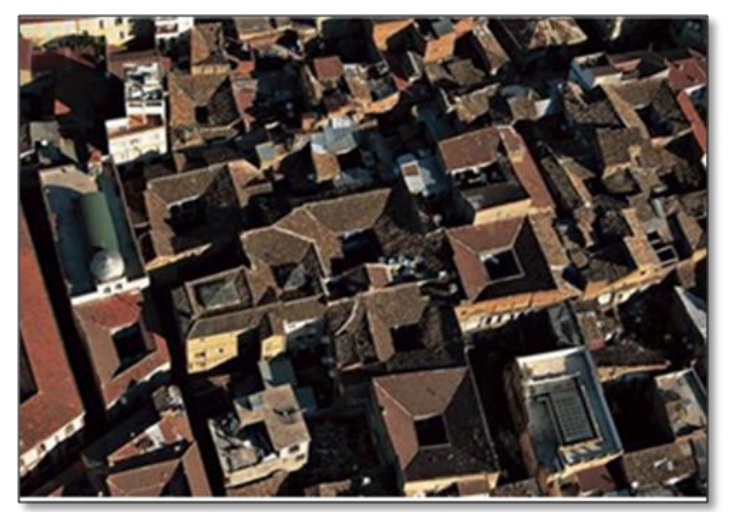

Figure 7. Aerial image of the Medina of Constantine (almost $95 \%$ of habitations have a patio) (Source: NASS, 2013) 


\subsubsection{Facade-induced thermal economy}

The habitation cluster (Derb Ben Cheikh El Feggoun) adopts the principle of compact fabric, whose habitation facades overlook two types of streets from which solar radiation is reduced almost to none.

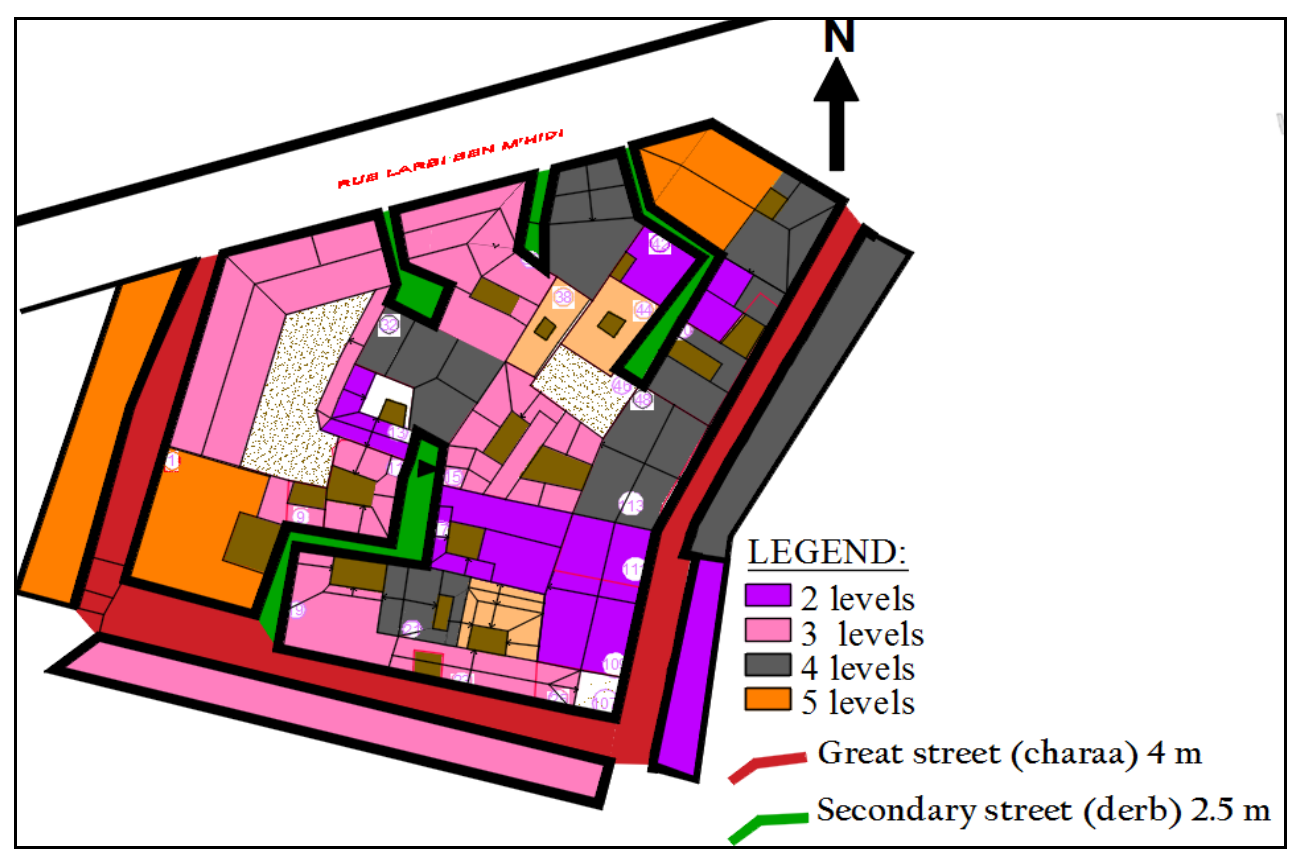

Figure 8. Case study plan: Habitation cluster Derb Ben Cheikh. (Source: authors)

There are two streets: (a) a 4 meters main street (red-colored) where the height of the buildings is 12 meters on both sides, allowing almost total shade on the facades; and (b) a 2.5 meters secondary street (green colored) surrounded by habitations with slightly different heights; however, the small size of this street allows creation of more shade on the facades.

A thermo-graphic survey has been developed based on all exterior facades located in the habitation cluster of Derb Ben Cheikh El Feggoun.

The thermo-graphic recording technique bears on the emission variation of electromagnetic radiation specific to each material. This radiant energy is a function of the surface temperature that is, in turn, conditioned in each material by the material-specific thermal conductivity and heat. These parameters provide quantitative characteristics of the materials to transmit and retain heat. Differences in the values of the parameters lead constituent materials to take different temperatures under thermal stress. These differences are measurable infractions of centigrade degree.

A thermo-graphic camera reads the flow of energy (electromagnetic radiation) emitted by the area and creates an image using infrared radiation. This energy flow appears on the camera with a reference color scale. Each element of the color scale corresponds to a temperature expressed in a fraction of a centigrade degree. The resulting image can be a photographic and/or video recording by performing a thermo-graphic plan or the change of the color bands corresponding to the isotherm lines.

Figure 9 demonstrates the heat reading for six successive days from 18 to 26 August 2020 at 2 p.m. The mean outdoor site temperature was $37^{\circ} \mathrm{C}$. 
The walls of the facades are constructed of stonemasonry and solid brick joined by a lime mortar binder. Dimensions vary between 40 and $80 \mathrm{~cm}$. The stone is used for both base in the ground floor and $4 \mathrm{~m}$ high retaining walls.

Figure 10 shows that the ground floor, built-in stone, and lime mortar in Building 1 has a temperature ranging from $23^{\circ} \mathrm{C}$ to $26^{\circ} \mathrm{C}$, as indicated by the yellow color. The other parts of the building, built mainly in solid bricks and joined by a lime mortar binder, have a temperature equal to $23^{\circ} \mathrm{C}$, as indicated by the green color. This fact comes to confirms that the brick is more competitive than the stone used on the ground floor.

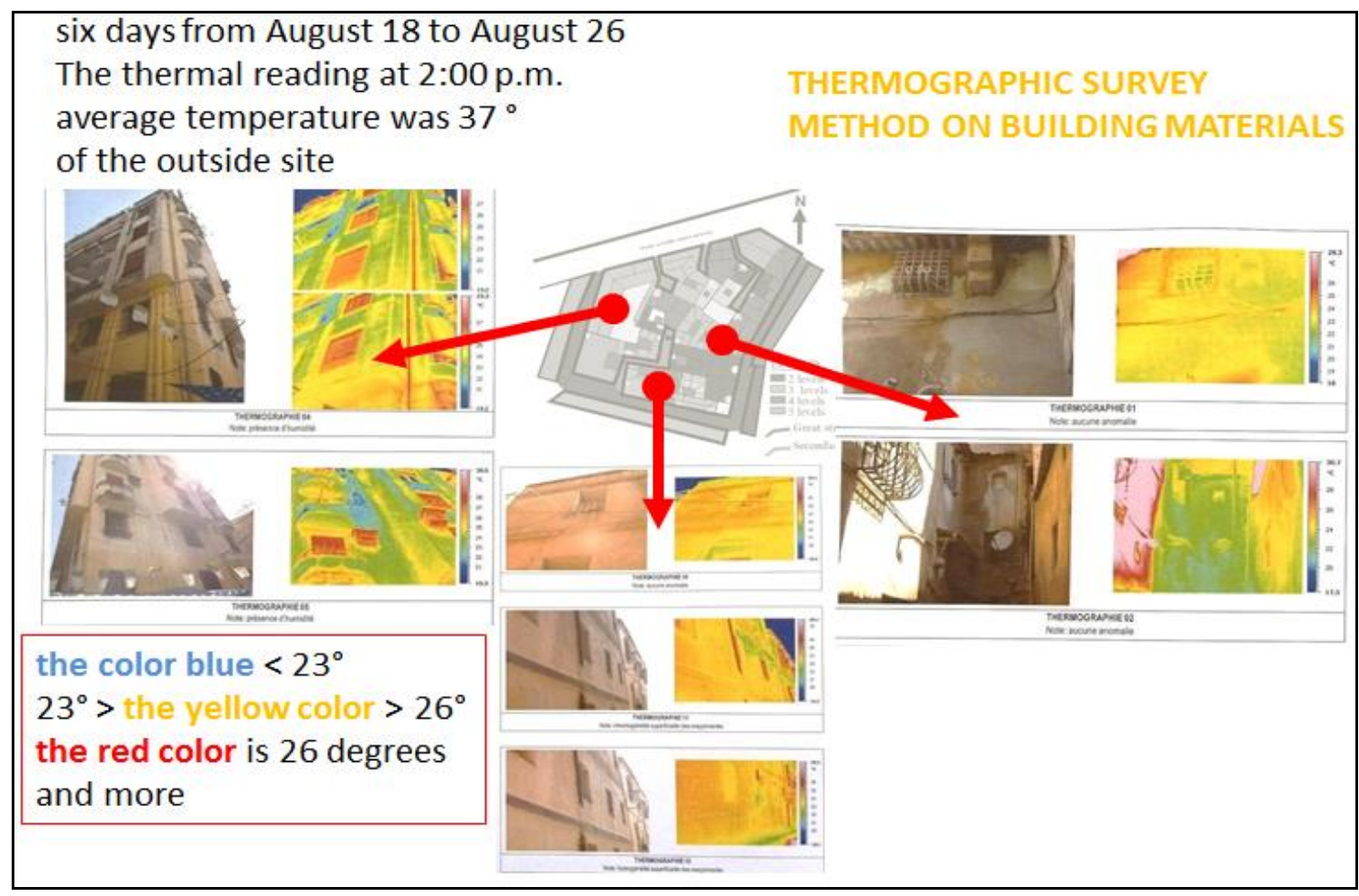

Figure 9. Thermal reading: Habitation cluster Derb Ben Cheikh. (Source: authors)

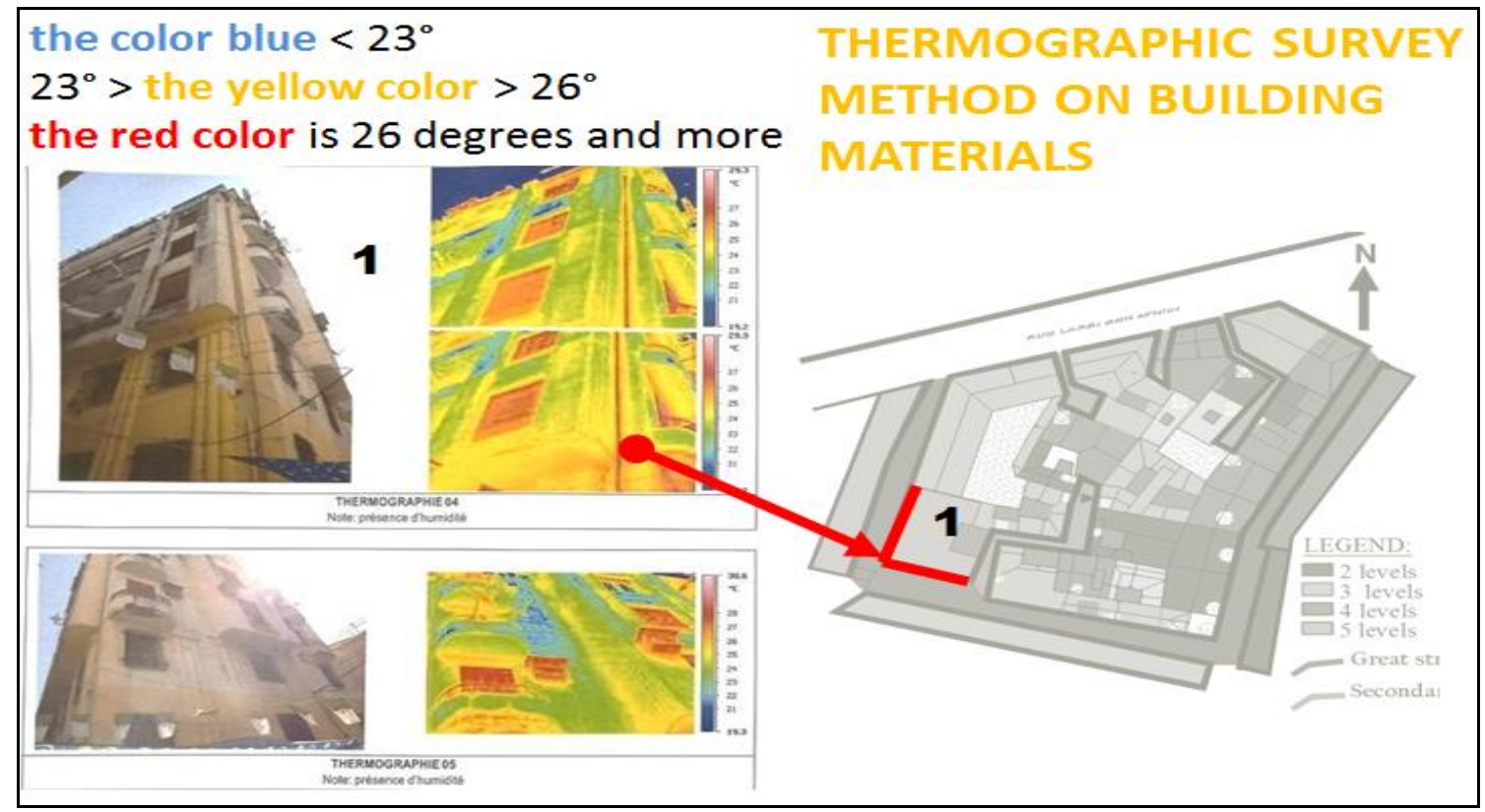

Figure 10. The thermal reading of Building 1. Habitation cluster Derb Ben Cheikh (Source: authors) 
Small spots of the building corners have a temperature lower than $23^{\circ} \mathrm{C}$, as indicated by the blue color, probably receiving little solar radiation and sunshine.

The red color, indicating heat absorption greater than $26^{\circ} \mathrm{C}$ with with a risk of inward conductivity, appears only on windows metal curtains. It is too precise that Building 1 is a classical period building in the habitation cluster of Derb Ben Cheikh, containing wide windows on its facades. This fact may help understand the reason why Arab habitations in the Medina of Constantine have openings in the patio rather than on the exterior facades.

The blue color, indicating a temperature lower than $23^{\circ} \mathrm{C}$, appears more in facade $\mathrm{A}$ of Building 2, which lies at the end of the cul-de-sac at the end of the smallest alley, receiving little solar radiation and heat.

The red color indicates higher heat absorption up to $26^{\circ} \mathrm{C}$.

The green color, indicating a temperature equal to $23^{\circ} \mathrm{C}$, appears on degraded walls built mainly in solid bricks and lacking in lime mortar. Therefore, these walls might have lost lose some of their characteristics.

It should be noted that habitations that have not been restored are threatened by degradation, and a few badly restored ones (with the introduction of cement mortar) may give conflicting results (Fantazi et al., 2018).

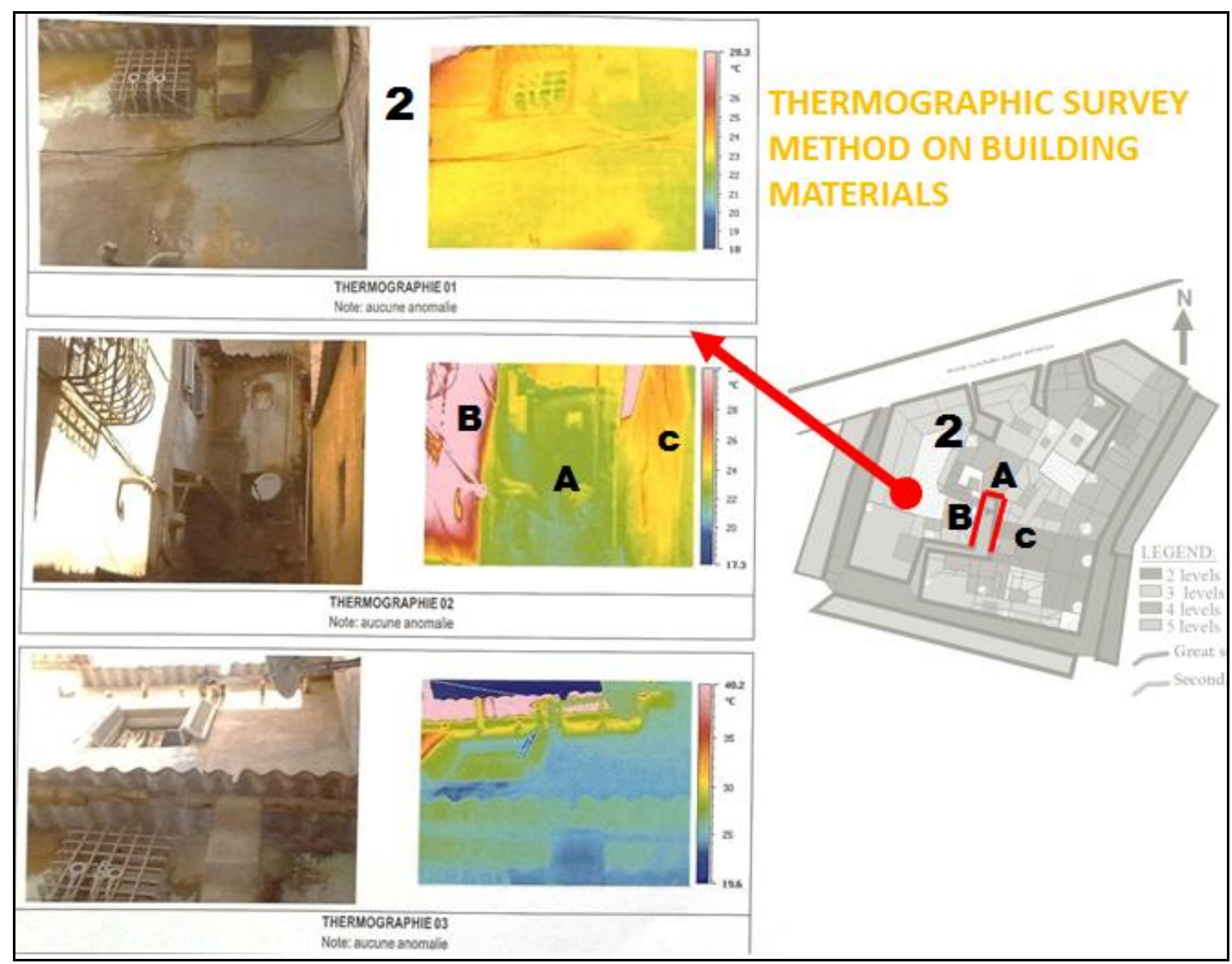

Figure 11. Thermal reading of Building 2. Habitation cluster Derb Ben Cheikh. (Source: authors)

To analyze previous experiments, another thermo-graphic survey was made of the patio of a central habitation number 15 of the cluster Derb Ben Cheikh. The created image shows an important dominance of the blue color, indicating a temperature lower than $23^{\circ} \mathrm{C}$, on the interior facades of the patio. 


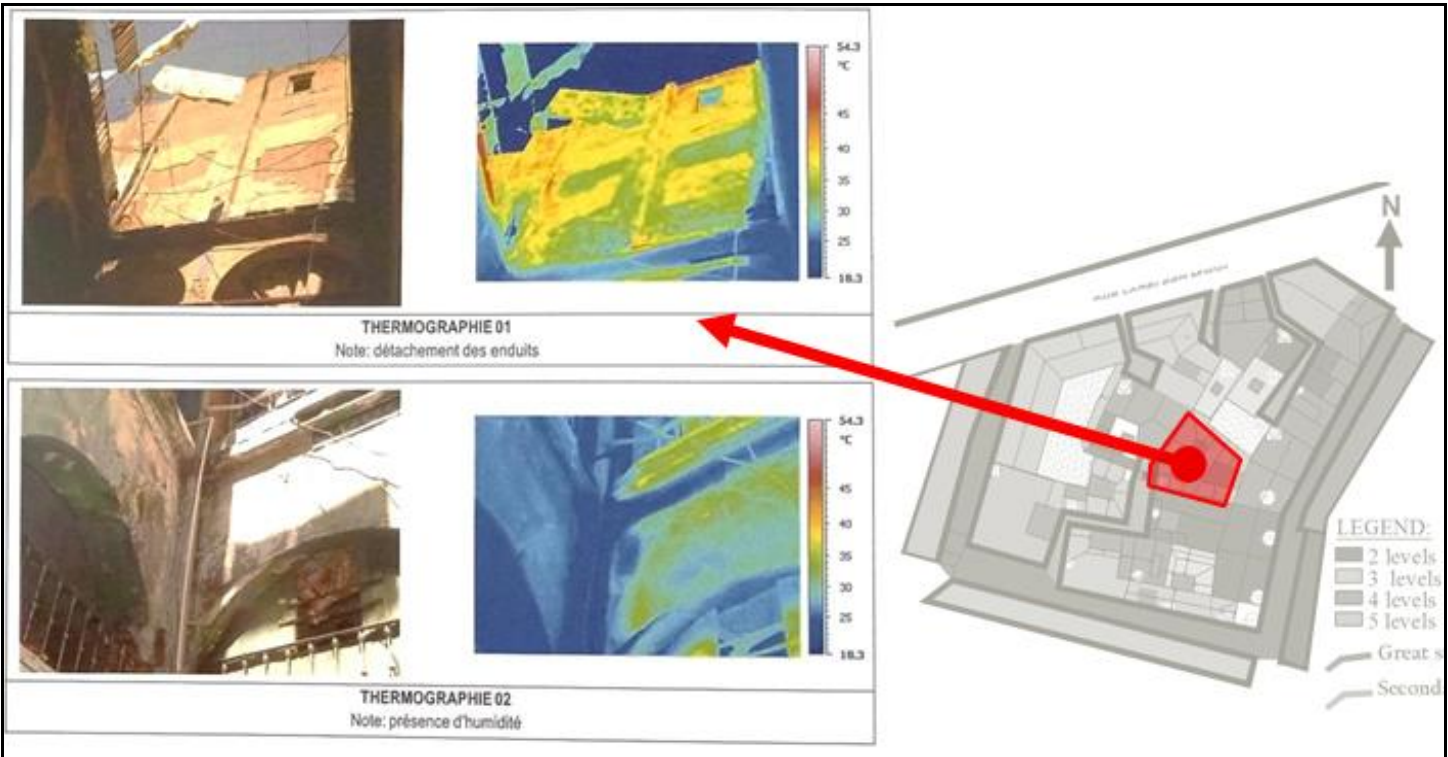

Figure 12. Thermal reading of the Central Building's Patio. Habitation cluster Derb Ben Cheikh Source: authors

On 18 August 2020 , with an outdoor site temperature of $37^{\circ} \mathrm{C}$, the following heat gains have been obtained in habitation number 15 :

- The mean temperature in the cul-de-sac was $30^{\circ} \mathrm{C}$.

- Mean temperature on the cul-de-sac walls was $32^{\circ} \mathrm{C}$.

- The ambient temperature in the patio was $26.6^{\circ} \mathrm{C}$.

- Temperature variation among the site and the cul-de-sac was seven ${ }^{\circ} \mathrm{C}$.

- Temperature variation among the outdoor site temperature and the patio was $10,4^{\circ} \mathrm{C}$.

It is worth mentioning that the example mentioned above is part of the culs-de-sac that are frequent in Medina. Basically, the cul-de-sac serves as an entry to several adjacent houses and is a common space for encounters and thermal comfort.

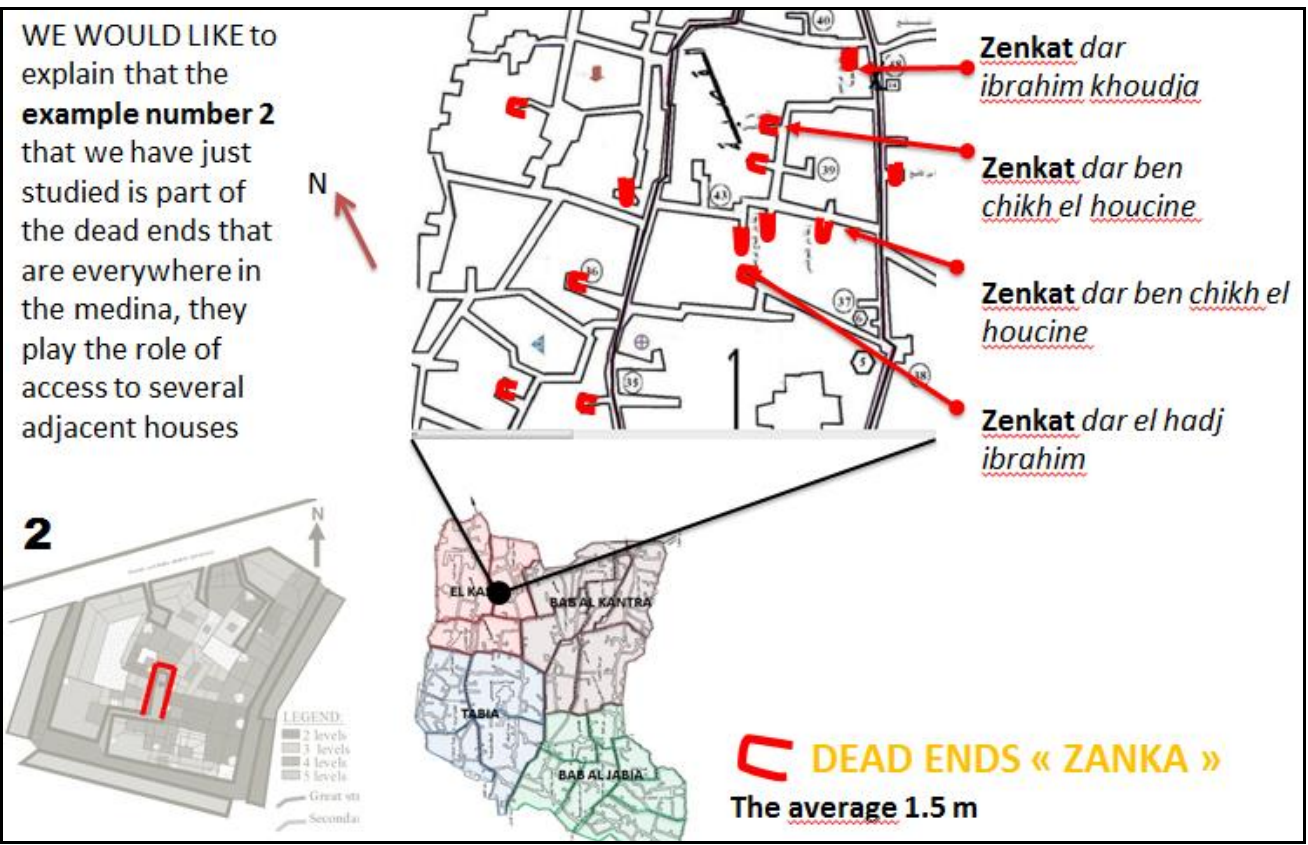

Figure 13. Medina's culs-de-sac (zenka). (Source: (NASS, 2013); modified by the authors) 


\subsection{Thermal economy induced by building materials (comparative method)}

The natural environment of the Medina is determined by climatic variation, solar movement, daily and seasonal cycles. This set of atmospheric conditions involves three essential climatic factors (Makaka \& Meyer, 2006).

- Solar radiation and temperatures,

- Air humidity and precipitation and drought, and

- The intensity, direction, and frequency of winds.

As demonstrated, the choice of building materials in Medina's habitations would contribute to a defensive optimization against these three climatic factors.

Earthenware brick is a generalized choice:

"These are walls built in earthenware brick, whose thickness varies between 30 and $70 \mathrm{~cm}$. The wall is wide at the base and decreases in thickness as it rises. The earthenware brick is $5 / 10 / 20 \mathrm{~cm}$ up to $25 \mathrm{~cm}$ in length. The laying of the earthenware brick is ensured by the lime mortar. This type of wall plays a very important role in the traditional structure, especially on the upper floors, where the weight of the building needs to be reduced. Additionally, earthenware brick wall has good acoustic and thermal insulation properties. These are brickworks that use elements of pressed clay, sometimes mixed with straw, and dried in the sun. The choice of use of earthenware brick is reasoned mainly to economic facts" (NASS, 2013).

Following information on health and ecological impact, it is to note that concrete masonry units, full aggregate concrete, common plaster, and mortar, which are frequently used in modern habitations, are not recommended building materials (Dinaer, 2016).

- Health impact of product: estimation of low breathing capacity from releases of harmful substances during use (Wells et al, 1998).

- Ecological impact of product: estimation of recycling potential and renewability characteristics of raw material from grey energy (extraction, production, and transport) (Abanda et al, 2014).

However, raw earthenware bricks and limestone, which are often used in Medina's habitations, are recommended for their health and ecological impact (Adegun \& Adedeji, 2017).

Table 2. Comparison of thickness and thermal resistance R of materials, (Haynes et al., 2014).

\begin{tabular}{lc}
\hline Material & Thickness (in $\mathbf{~ c m}$ ) for $\mathbf{R}=\mathbf{3} \mathbf{~ m}^{\mathbf{2} . \mathbf{K} / \mathbf{W}}$ \\
\hline Aerogel & $0.24 \mathrm{~cm}$ \\
Vacuum insulation & $2,4 \mathrm{~cm}$ \\
Polyurethane & $7-9 \mathrm{~cm}$ \\
Polyisocyanurate & $7 \mathrm{~cm}$ \\
Glass wool & $9-12 \mathrm{~cm}$ \\
Expanded polystyrene & $9-12 \mathrm{~cm}$ \\
Extruded polystyrene (Depron) & $10-12 \mathrm{~cm}$ \\
Rockwool & $10-12 \mathrm{~cm}$ \\
\hline
\end{tabular}




\begin{tabular}{lc}
\hline Cellulose wadding & $11-12,5 \mathrm{~cm}$ \\
Linen wool & $11-12,5 \mathrm{~cm}$ \\
Expanded wood or wood wool & $12-13,5 \mathrm{~cm}$ \\
Bulk hemp & $12 \mathrm{~cm}$ \\
Expanded cork & $13,5 \mathrm{~cm}$ \\
Straw & $16,5-22,5 \mathrm{~cm}$ \\
Particle board & $33 \mathrm{~cm}$ \\
Bioclimatic brick & $33 \mathrm{~cm}$ \\
Hemp brick $400 \mathrm{~kg} / \mathrm{m3}$ & $36 \mathrm{~cm}$ \\
Aerated concrete & $42-70 \mathrm{~cm}$ \\
Heavy wood & $60 \mathrm{~cm}$ \\
Hollow breeze blocks & $280 \mathrm{~cm}$ \\
Solid bricks & $300 \mathrm{~cm}$ \\
Limestone & $420 \mathrm{~cm}$ \\
Granite & $840 \mathrm{~cm}$ \\
\hline
\end{tabular}

Table 3 shows frequently used materials in Algerian buildings, materials' conductivity variation, and indicates the required thickness to obtain a surface thermal resistance of $\mathrm{R}=3 \mathrm{~m}^{2} . \mathrm{K} /$ Wis indicated.

$$
\mathrm{R}=3 \mathrm{~m}^{2} \cdot \mathrm{K} / \text { Wis }
$$

It should be noted that the value of $3 \mathrm{~m}^{2} . \mathrm{K} / \mathrm{W}$ for $\mathrm{R}$ (thermal resistance) is lower than the minimum required in France for example (Castaño, 2017), in Algeria, these building standards have not yet been introduced for recommended thermal resistances, where, since 1 January 2013, all new constructions must be low-consumption buildings and the building shell must therefore be of high performance (Medjelakh \& Abdou, 2008).

For the insulation of opaque walls, the recommended thermal resistances must be greater than or equal to $R=8 \mathrm{~m}^{2} . \mathrm{K} / \mathrm{W}$ in the attic and $\mathrm{R}=4 \mathrm{~m} 2 . \mathrm{K} / \mathrm{W}$ in walls and floors to meet the energy-saving objective of the project.

Comparison of several materials frequently used in buildings' construction yielded varying thermal conductivities. The choice of these materials was based on the following criteria:

- Hollow breeze blocks: $280 \mathrm{~cm}$

- Solid bricks: $300 \mathrm{~cm}$

- Limestone: $420 \mathrm{~cm}$

- Granite: $840 \mathrm{~cm}$

- These materials' use is very popular locally to build partitions and walls;

- These materials can be used alone without the need for further insulators;

- Their thicknesses are close; and

- These materials are affordable to build walls compared to other expensive ones unchosen herein. 
Though not known in the construction period of the Medina during the Turkish and Arab era, breeze block was considered in the study for comparison purposes, being currently a widely used building material.

This comparison clarifies that there is an average thickness of 300 and $420 \mathrm{~cm}$ for the two materials used in the walls of the house of Medinois (solid brick, limestone). Both materials (solid brick, limestone) are also non-polluting (according to Table 03) and can be prepared locally on-site, unlike the other two (cinder block and granite) (Atolagbe \& Fadamiro, 2014). That will require machining production and release air pollution with dust. Plant machines that consume fuel that pollutes the environment, adding the transport of these two materials from the plant to the site will also contribute to the increase in the cost of production (Chelghoum \& Belhamri, 2011).

\subsubsection{Heat transmission:}

As shown in Table 4, the thickness of $300 \mathrm{~cm}$ of the solid brick gives a thermal resistance $R=3 \mathrm{~m}^{2} . \mathrm{K} / \mathrm{W}$ (lower than the standard four $\mathrm{m}^{2} . \mathrm{K} / \mathrm{W}$ ). The thickness of the habitation walls of our study juxtaposed buildings varies between $500 \mathrm{~cm}$ and $700 \mathrm{~cm}$. (NASS, 2013)

The Algerian law and what was recommended to Technical Recommendation Document (February 2014) are necessary to emphasize therein: "Confined masonry that can provide high inertia to promote energy efficiency of the shell, soil, stabilized earthenware brick and stone are recommended for use in the load-bearing wall. They ensure, by the necessary thickness, stability and high inertia that regulates the thermal amplitudes". Accordingly, Medina's habitation example is particularly relevant to our study interest and lends support to our claim on building materials of the central habitation.

Table 3. Comparison of Thermic Conductivity among Adobe, Brick, and Earth (Source: Haynes et al., 2014).

\begin{tabular}{lc}
\hline \multicolumn{1}{c}{ Material } & $\begin{array}{c}\text { Thermal conductivity }\left(\mathbf{W} \cdot \mathbf{m}^{-\mathbf{1}} \cdot \mathbf{K}^{\mathbf{- 1}}\right) \text { Values } \\
\text { for a temperature of } \mathbf{2 0}^{\circ} \mathbf{C}\end{array}$ \\
\hline Adobe (raw earth) & 0,32 \\
Brick (terracotta) & $0,84^{3}$ \\
Earth (dry) & 0,75 \\
Air (100 kPa) & 0,0262 \\
Concrete & $0,92^{\underline{3}}$ \\
Glass & $1,2^{\underline{3}}$ \\
\hline
\end{tabular}

The elaborated comparison between the building materials showed that the choice of the use of large size solid brick and local limestone in the habitations of Constantine is highly recommended, as it increases habitations' inertia and is eco-friendly (Table 3 and 5)." In 136 academic out puts from 17 African countries. earthen construction materials are generally cheaper, cleaner and more thermally comfortable. Notwithstanding the advantages, the level of uptake is presently low. Earthen materials' strength and durability are key limitations" (Adegun \& Adedeji, 2017). 


\section{Discussion}

Nowadays, flats attract light and air towards the interior through openings commonly known as side facades so as to have repetitive glass windows on the buildings for lack of buildable space. These buildings are becoming increasingly close together, giving rise to an undesirable closed view, with balconies allowing noise and dust in. However, in Medina, there is no land issue, being an important economic factor, for the juxtaposition of habitations and narrow streets cause neither noise nor dust. Light and sun are provided by the interior of the habitation and not by the facades, while the air is purified and even conditioned by the patio.

In the vernacular habitation, green space and water are brought into the patio from the exterior. The narrow streets between the habitations often soften the temperature in summer and winter, and the adjoining Medina prevents winds and dust from entering the interior of the habitations, leaving room for conditioned air. The Medina's habitation meets enduring architectural and technical requirements due to its introverted typology. This typology is flexible as it shifts from one scale to another following the size of the Medina. It is a functional concept proven by a common social and spiritual strategy among the population and helps safeguard social customs for the coming generations. This type of habitation is profitable as its building materials are significantly economical, natural, and eco-friendly.

\section{Conclusion}

The present study lends further support to researchers' claims on the importance of the Medina's habitation in the face of climatic aggressiveness at times with its architecture and its building materials. The Medina's habitations constantly adopted enduring, soft, and sustainable solutions, as they were built with highly insulating materials and designed with a functional spirit, calling upon ventilation patios and juxtaposition of habitations.

Noteworthy, however, the medina habitat did not have the technological means, but its architecture made use of soft means to preserve some physical comfort and reduce greenhouse gas emissions.

The site's well-chosen materials, formed by the site's natural typology, fit perfectly with the climate in which they originate and give better resistance to materials' overflow, not to mention their availability and affordable cost compared to other costly ones.

\section{References}

1. Abanda, H.F.; Nkeng, G.E.; Tah, J.H.M.; Ohandja, E.N.F.; Manjia, M.B. (2014) Embodied energy and $\mathrm{CO} 2$ analyses of mud-brick and cement-block houses. AIMS Energy, 2, 1, pp 18-40.

2. Adegun, O.B.; Adedeji, Y.m. (2017) Review of economic and environmental benefits of earthen materials for housing in Africa. Frontiers of Architectural Research , 6, pp 519-528.

3. Agence National des secteurs sauvegardés (NASS). (2013) PPSMVSS vieille ville de Constantine, phase III: rédaction finale du PPSMVSS, City Hall of Constantine, Algeria.

4. Al-MudhafferaSaif, A.F.; Saleh, S.K.; Kadhum, G.I. (2021) the role of sustainable materials in reducing building temperature. Materials today: proceedings. 
5. Atolagbe, A.M.O.; Fadamiro, J. (2014) Indigenous African building techniques and the prospects for sustainable housing and environmental development, Environment, Development and Sustainability, 16, pp 1041-1051.

6. Azzag, E.B. (2011) Projet urbain connaitre le contexte du développement urbain, Edition synergie, Paris, pp. 245.

7. Bouchareb, A. Cirta ou le substratum urbain de Constantine : La région, la ville et l'architecture dans I'antiquité. Doctoral thesis, Institute of architecture and town planning, University Frères Mentouri, Constantine, 2006.

8. Castaño, J.O. (2017) L'écoconception de bâtiments et de matériaux de construction face aux défis des territoires durables : l'échelle des écoquartiers, prospectives et définition des indicateurs. Géographie.

9. Chaouche, B.M. La micro-urbanisation et la ville oasis une alternative à l'équilibre des zones arides pour une ville saharienne durable cas du bas-Sahara. Doctoral thesis, Institute of architecture and town planning, University Frères Mentouri, Constantine, 2007.

10. Chelghoum, Z. ; Belhamri, Z. (2011) Analyse des propriétés thermiques des matériaux de constructions utilisés dans la ville de Tamanrasset, Sciences \& Technologi ; 33, pp.47-56.

11. Dekoumi, D. Pour une nouvelle politique de conservation de l'environnement historique bâti algérien cas de Constantine. Doctoral thesis, Institute of architecture and town planning, University Frères Mentouri, Constantine, 2007.

12. Demazièr, D.; Giraud, O.; Lallement, M. (2013) Comparer. Options and inflections in ways of doing research. sociologie du travail, OpenEdition, 55, 2, pp. 136-151.

13. Dinaer, L. Les enjeux liés aux matériaux de construction mise en contexte et dernières évolutions. séminaire bâtiment durable, Bruxelles, 2016.

14. Dzmeteo. https://www.dzmeteo.com/ (accessed 18 August 2020).

15. Fantazi, I.; Hecham, Z.B.; Petrisor, A.I. (2019) The impact of the absence of communication on the success of rehabilitation projects of the built heritage: the case of the old city of Constantine, PESD,13, 1, pp. 225-239.

16. Fantazi, I.; Hecham, Z.B. (2018) Les facteurs de l'échec des opérations de conservation du patrimoine bâti dans la vieille ville de Constantine, Sciences \& Technologie, 48, pp. 107-118.

17. Fethi, H. (1977) Construire avec le peuple, Edition Sindbad. ; Paris.

18. Grangaud, I. la Ville imprenable, histoire sociale de Constantine aux 18éme siècles. Doctoral thesis, Paris School of Higher Studies in Social Sciences, Paris, 1998.

19. Haynes, W. M.; Lide, D.R.; Bruno, T.J. (2014) Handbook of Chemistry and Physics. Editor in chief, 95th edition.

20. Khenoucha, T. (2010) De la permanence et du changement dans la genèse de l'espace public de la vielle ville de Constantine, Sciences \& Technologie, 31, pp. 15-24.

21. Kherouatou, M. L"enjeu majeur d'un projet urbain de réhabilitation, cas de la vieille ville de Constantine. Magister thesis, Institute of architecture and urban planning, University Frères Mentouri, Constantine, 2011.

22. Lacaze, J.P. (2014) Les méthodes de I'urbanisme, PUF Collection : que sais-je.

23. Makaka, G.; Meyer, E. (2006) Temperature stability of traditional and low-cost modern housing in the Eastern Cape, South Africa, Journal of Building Physics, 30, 1.

24. Medjelakh, D.; Abdou, A. (2008) Impacte de l'inertie thermique sur le confort hygrothermique et la consommation énergétique du bâtiment. Revue des énergies renouvelables, 11,3, pp. 329-341.

25. Mouline, S. (1981) La ville et la maison arabo-musulmane. Édition 2, Centre national de documentation pédagogique, Paris.

26. Organisation des Nations Unies pour l'éducation, la science et la culture. Conference international de Rio pour le développement durable, Rio de Janeiro Brésil, 1992. 
27. Plemenka, S. (1982) L'aspect bioclimatique de I'habitat vernaculaire. Arch. \& comport. /Arch. \& Behav., 10,1, pp.32.

28. Wells, J.; Sinda, S.H.; Haddar, F. (1998) Housing and building materials in low-income settlements in Dar es Salaam. Habitat International, 22,4, pp. 397-409

(c) 2021 by the authors. Licensee UAIC, Iasi, Romania. This article is an open access article distributed under the terms and conditions of the Creative Commons Attribution (CC BY-NC-ND) license (https://creativecommons.org/licenses/by-nc-nd/4.0). 